\title{
Anti-cancer activity of Ginger (Zingiber officinale) leaf through the expression of activating transcription factor 3 in human colorectal cancer cells
}

Gwang Hun Park ${ }^{1 \dagger}$, Jae Ho Park ${ }^{2 \dagger}$, Hun Min Song ${ }^{1 \dagger}$, Hyun Ji Eo ${ }^{1}$, Mi Kyoung Kim', Jin Wook Lee ${ }^{1}$, Man Hyo Lee ${ }^{3}$, Kiu-Hyung Cho ${ }^{3}$, Jeong Rak Lee ${ }^{3}$, Hyeon Je Cho ${ }^{3}$ and Jin Boo Jeong ${ }^{1,45^{*}}$

\begin{abstract}
Background: Ginger leaf (GL) has long been used as a vegetable, tea and herbal medicine. However, its pharmacological properties are still poorly understood. Thus, we performed in vitro studies to evaluate anti-cancer properties of ginger leaf and then elucidate the potential mechanisms involved.

Methods: Cell viability was measured by MTT assay. ATF3 expression level was evaluated by Western blot or RT-PCR and ATF3 transcriptional activity was determined using a dual-luciferase assay kit after the transfection of ATF3 promoter constructs. In addition, ATF3-dependent apoptosis was evaluated by Western blot after ATF3 knockdown using ATF3 siRNA.

Results: Exposure of GL to human colorectal cancer cells (HCT116, SW480 and LoVo cells) reduced the cell viability and induced apoptosis in a dose-dependent manner. In addition, GL reduced cell viability in MCF-7, MDA-MB-231 and HepG-2 cells. ATF3 knockdown attenuated GL-mediated apoptosis. GL increased activating transcription factor 3 (ATF3) expressions in both protein and mRNA level and activated ATF3 promoter activity, indicating transcriptional activation of ATF3 gene by GL. In addition, our data showed that GL-responsible sites might be between -318 and -85 region of the ATF3 promoter. We also observed that ERK1/2 inhibition by PD98059 attenuated GL-mediated ATF3 expression but not p38 inhibition by SB203580, indicating ERK1/2 pathway implicated in GL-induced ATF3 activation.
\end{abstract}

Conclusions: These findings suggest that the reduction of cell viability and apoptosis by GL may be a result of ATF3 promoter activation and subsequent increase of ATF3 expression through ERK1/2 activation in human colorectal cancer cells.

Keywords: Ginger leaf, Cancer chemoprevention, Activating transcription factor 3, Apoptosis, Colorectal cancer

\section{Background}

Cancer is a major problem of public health in many other parts of the world including the United States [1]. Among the kinds of cancers, human colorectal cancer is the third leading cause of cancer-related death in both male and females in the United States [1]. Although

\footnotetext{
* Correspondence: jjb0403@anu.ac.kr

${ }^{\dagger}$ Equal contributors

'Department of Bioresource Sciences, Andong National University, Andong

760749, South Korea

${ }^{4}$ Insititute of Agricultural Science and Technology, Andong National

University, Andong 760749, South Korea

Full list of author information is available at the end of the article
}

surgery and chemotherapy have been the most common treatment for colorectal cancer, cancer chemoprevention with dietary factors has received attention as the most effective approach to reduce colorectal cancer-related mortality. Thus, for the last two decades, many researchers have tested and reported anti-cancer activities of natural products in dietary factors such as fruits, vegetables and teas $[2,3]$.

Gingers as perennial herbs belonging to the family Zingiberaceae have been widely used as spices, condiments and herbal medicine for treatment of cold, fever, headache, nausea and digestive problems [4]. Ginger and

\section{Biomed Central}

(c) 2014 Park et al.; licensee BioMed Central Ltd. This is an Open Access article distributed under the terms of the Creative Commons Attribution License (http://creativecommons.org/licenses/by/4.0), which permits unrestricted use, distribution, and reproduction in any medium, provided the original work is properly credited. The Creative Commons Public Domain Dedication waiver (http://creativecommons.org/publicdomain/zero/1.0/) applies to the data made available in this article unless otherwise stated. 
its general compounds such as gingerols, shogaols, paradols and zingerone exert immuno-modulatory, antiapoptotic, anti-tumourigenic, anti-inflammatory, antihyperglycaemic, anti-hyperlipidaemic, antioxidant and anti-emetic activities [4]. Ginger leaves have also been used for food flavouring and traditional medicine [5]. Past pharmacological studies of ginger were confined to rhizomes. Thus, in light of the pharmacological actions of ginger leaves, this study was performed to investigate the anti-cancer activity and elucidate the potential mechanism by which ginger leaves induces the reduction of cell viability and apoptosis in human colorectal cancer cells. Here, for the first time, we report that ginger leaves leads to transcriptional activation of activating transcription factor 3 (ATF3) which may be associated with the reduction of cell viability and induction of apoptosis in human colorectal cancer cells.

\section{Methods}

\section{Materials}

Cell culture media, Dulbecco's Modified Eagle medium (DMEM)/F-12 1:1 Modified medium (DMEM/F-12) was purchased from Lonza (Walkersville, MD, USA). The 3(4,5-dimethylthizaol-2-yl)-2,5-diphenyl tetrazolium bromide (MTT) and SP600125 was purchased from Sigma Aldrich (St. Louis, MO, USA). SB203580 and PD98059 were purchased from Calbiochem (San Diego, CA, USA). ATF3 antibody and ATF3 siRNA were provided from Santa Cruz Biotechnology, Inc (Santa Cruz, CA, USA). Antibodies against $\beta$-actin and poly (ADP-ribose) polymerase (PARP), and control siRNA were purchased from Cell Signaling (Bervely, MA, USA). ATF3 promoter constructs $(-1420 /+34,-718 /+34,-514 /+34,-318 /+34,-147 /+34$ and $-84 /+34)$ were kindly provided by Dr. S-H Lee (University of Maryland College Park, MD, USA). All chemicals were purchased from Fisher Scientific, unless otherwise specified.

\section{Sample preparation}

The leaves of ginger (Zingiber officinale, voucher number: PARK1003(ANH)) were kindly provided by the Bonghwa Alpine Medicinal Plant Experiment Station, Korea. One kilogram of ginger leaf was extracted with $1000 \mathrm{ml}$ of $80 \%$ methanol with shaking for $24 \mathrm{~h}$. After $24 \mathrm{~h}$, the methanolsoluble fraction was filtered and concentrated to approximately $20 \mathrm{ml}$ volume using a vacuum evaporator and then fractionated with petroleum ether and ethyl acetate in a separating funnel. The ethyl acetate fraction was separated from the mixture, evaporated by a vacuum evaporator, and prepared aseptically and kept in a refrigerator.

\section{Cell culture and treatment}

Human colorectal cancer cell lines (HCT116, SW480 and LoVo), human breast cancer cell lines (MCF-7 and
MDA-MB231) and human hepatocellular carcinoma (HepG-2) were purchased from Korean Cell Line Bank (Seoul, Korea) and grown in DMEM/F-12 supplemented with $10 \%$ fatal bovine serum (FBS), $100 \mathrm{U} / \mathrm{ml}$ penicillin and $100 \mu \mathrm{g} / \mathrm{ml}$ streptomycin. The cells were maintained at $37^{\circ} \mathrm{C}$ under a humidified atmosphere of $5 \% \mathrm{CO}_{2}$. The extracts of ginger leaf (GL) were dissolved in dimethyl sulfoxide (DMSO) and treated to cells. DMSO was used as a vehicle and the final DMSO concentration did not exceed $0.1 \%(\mathrm{v} / \mathrm{v})$.

\section{Cell viability}

Cell viability was measured using MTT assay system. Briefly, cells were plated onto 96-well plated and grown overnight. The cells were treated with $0,50,100$ and $200 \mu \mathrm{g} / \mathrm{ml}$ of GL for 24 and $48 \mathrm{~h}$. Then, the cells were incubated with $50 \mu \mathrm{l}$ of MTT solution $(1 \mathrm{mg} / \mathrm{ml})$ for an additional $2 \mathrm{~h}$. The resulting crystals were dissolved in DMSO. The formation of formazan was measured by reading absorbance at a wavelength of $570 \mathrm{~nm}$.

\section{Reverse transcriptase-polymerase chain reaction (RT-PCR)}

Total RNA was prepared using a RNeasy Mini Kit (Qiagen, Valencia, CA, USA) and total RNA $(1 \mu \mathrm{g})$ was reversetranscribed using a Verso cDNA Kit (Thermo Scientific, Pittsburgh, PA, USA) according to the manufacturer's protocol for cDNA synthesis. PCR was carried out using PCR Master Mix Kit (Promega, Madison, WI, USA) with primers for human ATF3 and human GAPDH as follows: human ATF3: 5'-gtttgaggattttgctaacctgac-3', and reverse 5 '-agctgcaatcttatttcttctcgt-3'; huaman GAPDH: forward $5^{\prime}$-acccagaagactgtggatgg- $3^{\prime}$ and reverse $5^{\prime}$-ttctagacggcaggt caggt-3'.

\section{Transient transfections}

Transient transfections were performed using the Polyjet DNA transfection reagent (SignaGen Laboratories, Ijamsville, MD, USA) according to the manufacturers' instruction. HCT116 and SW480 cells were plated in 12-well plates at a concentration of $2 \times 105$ cells/well. After growth overnight, plasmid mixtures containing $0.5 \mu \mathrm{g}$ of ATF3 promoter linked to luciferase and $0.05 \mu \mathrm{g}$ of $p R L$-null vector were transfected for $24 \mathrm{~h}$. The transfected cells were cultured in the absence or presence of GL for the indicated times. The cells were then harvested in $1 \times$ luciferase lysis buffer, and luciferase activity was normalized to the $p R L$-null luciferase activity using a dual-luciferase assay kit (Promega, Madison, WI, USA).

\section{Transfection of small interference RNA (siRNA)}

The cells were plated in six-well plates and incubated overnight. HCT116 cells were transfected with control siRNA and ATF3 siRNA for $48 \mathrm{~h}$ at a concentration of $100 \mathrm{nM}$ using TransIT-TKO transfection reagent (Mirus, 
Madison, WI, USA) according to the manufacturer's instruction. Then the cells were treated with GL $(100 \mu \mathrm{g} / \mathrm{ml})$ for $24 \mathrm{~h}$.

\section{Cell death assay}

Cell death was performed using Cell Death Detection ELI$\mathrm{SA}^{\text {PLUS }}$ Kit (Roche Diagnostics, Indianapolis, IN, USA) according to the manufacturer's instruction. Briefly, HCT116 and SW480 cells were seeded in 12-well plate. After $24 \mathrm{~h}$, cells were treated with $0,25,50$ and $100 \mu \mathrm{M}$ of GL for 24 h. Cytosol was prepared using Nuclear Extract Kit (Active Motif, Carlsbad, CA, USA). Equal amounts of cytosolic extracts, immunoreagent containing anti-histonebiotin, and anti-DNA-POD were added to microplate well and incubated for $2 \mathrm{~h}$ under shaking. After washing, the ABTS solution was added to each well for $20 \mathrm{~min}$ and then the ABTS stop solution was added. The absorbance was recorded at $405 \mathrm{~nm}$ and 490 .

\section{SDS-PAGE and Western blot}

After GL treatment, cells were washed with $1 \times$ phosphate-buffered saline (PBS), and lysed in radioimmunoprecipitation assay (RIPA) buffer (Boston Bio Products, Ashland, MA, USA) supplemented with protease inhibitor cocktail (Sigma-Aldrich, St. Louis, MD. USA) and phosphatase inhibitor cocktail (Sigma-Aldrich), and centrifuged at $15,000 \times \mathrm{g}$ for $10 \mathrm{~min}$ at $4^{\circ} \mathrm{C}$. Protein concentration was determined by the bicinchoninic acid (BCA) protein assay (Pierce, Rockford, IL, USA). The proteins were separated on SDS-PAGE and transferred to PVDF membrane (Bio-Rad Laboratories, Inc., Hercules, CA, USA). The membranes were blocked for non-specific binding with $5 \%$ non-fat dry milk in Tris-buffered saline containing $0.05 \%$ Tween 20 (TBS-T) for $1 \mathrm{~h}$ at room temperature and then incubated with specific primary antibodies in $5 \%$ non-fat dry milk at $4{ }^{\circ} \mathrm{C}$ overnight. After three washes with TBS-T, the blots were incubated with horse radish peroxidase (HRP)-conjugated immunoglobulin $\mathrm{G}$ (IgG) for $1 \mathrm{~h}$ at room temperature and chemiluminescence was detected with ECL Western blotting substrate (Amersham Biosciences, Piscataway, NJ, USA) and visualized in Polaroid film.

\section{Statistical analysis}

Statistical analysis was performed with the Student's unpaired $t$-test, with statistical significance set at *, $\mathrm{P}<0.05$.

\section{Results}

\section{Effect of GL on cell viability and apoptosis}

To investigate whether ginger leaf affects the cell viability in human colorectal cancer cells, HCT116, SW480 and LoVo, the cells were incubated with 50, 100 and $200 \mu \mathrm{g} / \mathrm{ml}$ of GL for 24 and $48 \mathrm{~h}$, and cell viability was measured using MTT assay. As shown in Figure 1A, GL reduced the viability of HCT116 cells by 24 and $59 \%$ at $50 \mu \mathrm{g} / \mathrm{ml}, 53$ and $79 \%$ at $100 \mu \mathrm{g} / \mathrm{ml}$, and 79 and $88 \%$ at $200 \mu \mathrm{g} / \mathrm{ml}$ at 24 and $48 \mathrm{~h}$ after GL treatment, respectively. We also found that the viability of SW480 cells was reduced by GL treatment for 24 and 48 h by 23 and $40 \%$ at $50 \mu \mathrm{g} / \mathrm{ml}, 42$ and $57 \%$ at $100 \mu \mathrm{g} / \mathrm{ml}$, and 55 and $76 \%$ at $200 \mu \mathrm{g} / \mathrm{ml}$, respectively (Figure $1 \mathrm{~B}$ ). In addition, GL suppressed LoVo cell viability by 20 and $33 \%$ at $50 \mu \mathrm{g} / \mathrm{ml}, 34$ and $55 \%$ at $100 \mu \mathrm{g} / \mathrm{ml}$, and 59 and $80 \%$ at $200 \mu \mathrm{g} / \mathrm{ml}$ after GL treatment for 24 and $48 \mathrm{~h}$, respectively (Figure 1C). HCT116 and SW480 cells were treated with 25,50 and $100 \mu \mathrm{g} / \mathrm{ml}$ of GL for $24 \mathrm{~h}$, and apoptosis was measured using Western blot against cleaved PARP and the cell death assay using ELISA-based cell death kit. As shown in Figure 1D, the cleavage of PARP was observed at 50 and $100 \mu \mathrm{g} / \mathrm{ml}$ in HCT116 and SW480 cells, respectively, which indicates that GL may induce apoptosis. In addition, significant increases of cell death were observed in the cells treated with GL (Figure 1E). To determine if GL shows a reduction of cell viability in other types of cancer cells, breast (MCF-7 and MDA-MD-231) and hepatocellular carcinoma (HepG-2) cells were treated with $100 \mu \mathrm{g} / \mathrm{ml}$ at $24 \mathrm{~h}$. As a result, GL-treatment for $24 \mathrm{~h}$ reduced the cell viability by $36 \%$ in MCF-7, $44 \%$ in MDA-MB-231, and $30 \%$ in HepG-2 cells, respectively (Figure 1F). These data indicates that GL may have anti-cancer activity in colorectal cancer, breast cancer and hepatocellular carcinoma cells.

\section{Effect of GL on ATF3 expression in HCT116 and SW480 cells}

Since there is growing evidence that ATF3 is associated with to cell growth arrest and apoptosis in human colorectal cancer cells [6], we evaluated whether GL affects ATF3 expression in HCT116 and SW480 cells. As shown in Figure 2A-D, GL-induced ATF3 expressions were observed at 50 and $100 \mu \mathrm{g} / \mathrm{ml}$ of GL in both protein and mRNA level. To investigate whether increase in ATF3 expression by GL treatment was mediated from transcription activation of ATF3 promoter, ATF3 promoter $(-1420 /+34)$ transfected HCT116 and SW480 cells were incubated with 25, 50 and $100 \mu \mathrm{g} / \mathrm{ml}$ of GL for $24 \mathrm{~h}$. As shown in Figure 2E and F, GL dose-dependently activated ATF3 transcription. In time-course experiments, we found that the expression of ATF3 mRNA activation by GL started to be increased at $1 \mathrm{~h}$ after GL treatment in HCT116 cells (Figure 2G). To see whether ATF3 expression affect GL-mediated apoptosis, cleaved PARP was measured by Western blot in ATF3 knock downed-HCT116 cells. As shown in Figure $2 \mathrm{H}$, knockdown of ATF3 by ATF3 siRNA reduced the cleavage of PARP by GL, indicating that ATF3 may be one of important genes in GL-mediated apoptosis.

\section{Kinases affecting GL-induced ATF3 activation}

To determine upstream kinase affecting GL-induced ATF3 transcriptional activation, ATF3 promoter $(-1420 /+34)$ 

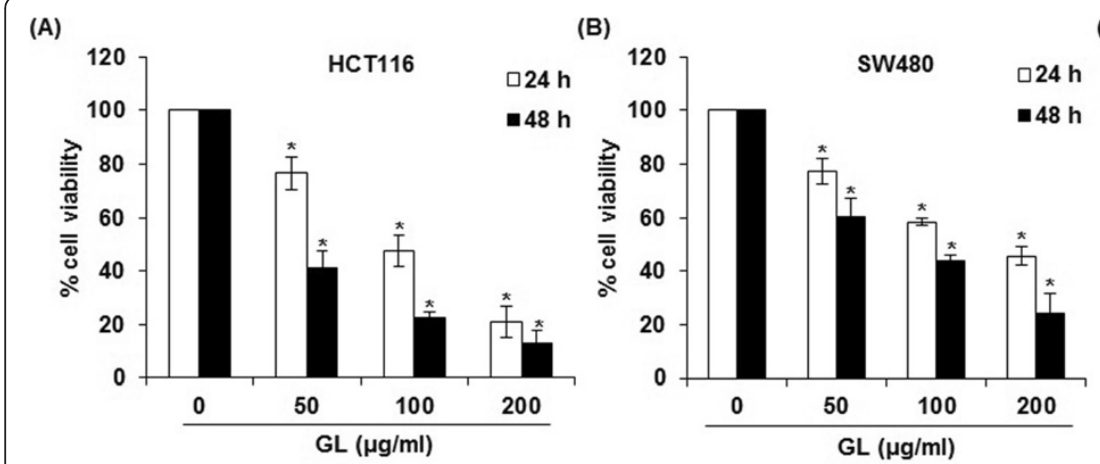

(D)

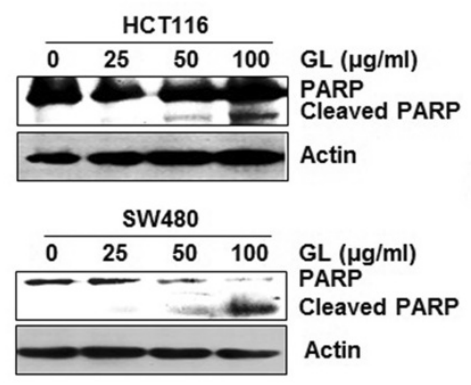

(E)

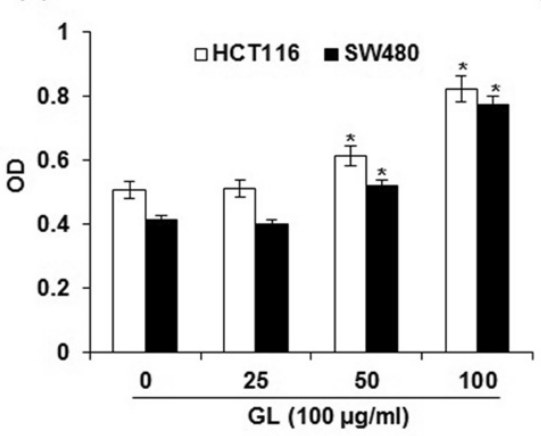

(C)

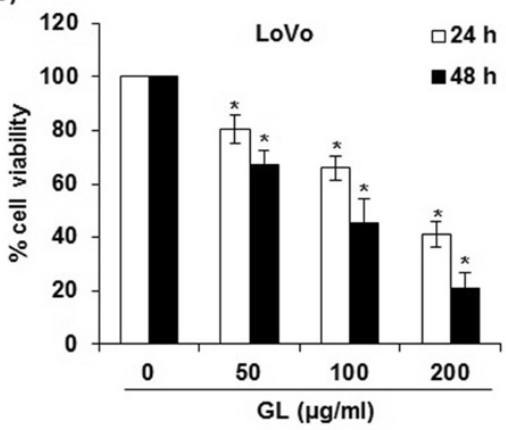

(F)

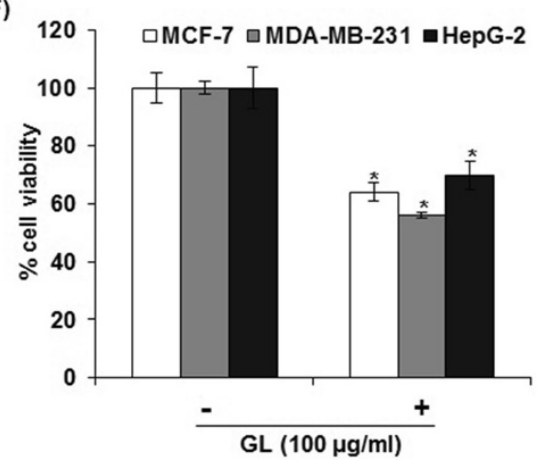

Figure 1 The effects of GL on cell viability and apoptosis in human colorectal cancer cells. HCT116 (A), SW480 (B) and LoVo cells (C) were treated with $0,50,100$ and $200 \mu \mathrm{g} / \mathrm{ml}$ of GL for 24 and $48 \mathrm{~h}$. Cell viability was measured using MTT assay system and expressed as \% cell viability compared to the cell without GL treatment. ${ }^{*} P<0.05$ compared to cells without GL treatment. (D) HCT116 and SW480 cells were treated with 0 , 25,50 and $100 \mu \mathrm{g} / \mathrm{ml}$ of GL for $24 \mathrm{~h}$. Cell lysates were subjected to SDS-PAGE and the Western blot was performed using antibodies against PARP. Actin was used as internal control. (E) HCT116 and SW480 cells were treated with 0, 25, 50 or $100 \mu \mathrm{M}$ of GL for 24 h. the cytosol fraction

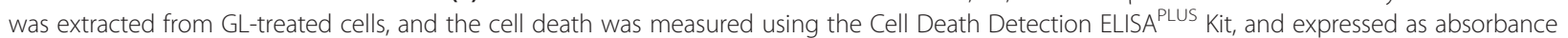
$\left(\mathrm{A}_{405}-\mathrm{A}_{490}\right)$. ${ }^{*} \mathrm{p}<0.05$ compared to cells without GL treatment. (F) MCF-7, MDA-MB-231 and HepG-2 cells were treated with $100 \mu \mathrm{g} / \mathrm{ml}$ of GL for $24 \mathrm{~h}$. Cell viability was measured using MTT assay system and expressed as \% cell viability compared to the cell without GL treatment. ${ }^{*} \mathrm{P}<0.05$ compared to cells without GL treatment.

transfected HCT116 and SW480 cells were pretreated with $20 \mu \mathrm{M}$ of PD98059 (ERK1/2 inhibitor) and SB203580 (p38 inhibitor) for $2 \mathrm{~h}$ and co-treated with $100 \mu \mathrm{g} / \mathrm{ml}$ of GL for $24 \mathrm{~h}$. As shown in Figure 3A and B, ERK1/2 inhibition by PD98059 attenuated GL-mediated ATF3 promoter activation, while p38 inhibition by SB203580 did not affect ATF3 activation by GL in both HCT116 and SW480 cells. We also investigated whether JNK signaling affects GL-mediated ATF3 promoter activation and found that JNK inhibition by SP600125 did not affect ATF3 promoter activation by GL (data not shown).

We investigated that GL treatment affects ERK1/2 activation. As shown in Figure $3 \mathrm{C}$ and D, GL enhanced phosphorylation of ERK1/2 protein. We also tested that the inhibitions of ERK1/2 by PD98059 and p38MAPK by SB203580 affect GL-mediated ATF3 protein level. In these experiments, the inhibition of ERK1/2 by PD98059 ameliorated the increase of ATF3 protein level by GL, while p38 MAPK inhibition did not affect ATF3 protein level in HCT116 cells (Figure 3E). Because GL-mediated
ATF3 activation was affected by ERK1/2, we evaluated if ERK1/2 affects GL-mediated apoptosis. As a result, ERK1/2 inhibition by PD98059 attenuated GL-mediated cleavage of PARP in HCT116 cells (Figure 3F). These results indicates that GL-mediated apoptosis may result from ERK1/2-dependent ATF3 activation.

\section{Identification of ATF3 promoter sites responsible for} GL-induced ATF3 activation

To investigate ATF3 promoter sites which can be responsible for GL-induced ATF3 activation, promoter activity was measured using different sizes of ATF3 promoter luciferase constructs $(-1420 /+34,-718 /+34,-514 /+34$, $-318 /+34,-147 /+34$ and $-84 /+34)$. These constructs were transfected into SW480 cells and treated with $100 \mu \mathrm{g} / \mathrm{ml}$ of GL for $24 \mathrm{~h}$. As shown in Figure 4A, GL treatment resulted in an increase of promoter activity. The fold induction in SW480 cells was 5.1, 5.0, 4.4, 4.2, 3.1 and 2.5 in pATF3-1420/+34, pATF3- 718/+ 34, pATF3- 514/+ 34, pATF3- 318/+ 34, pATF3-147/+ 34, 
(A)

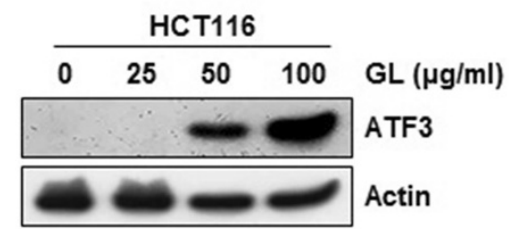

(C)

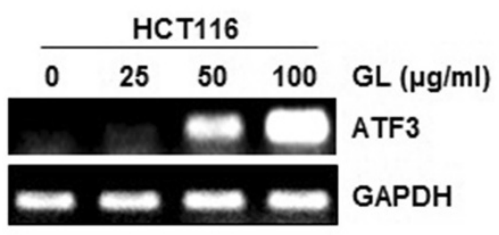

(E)

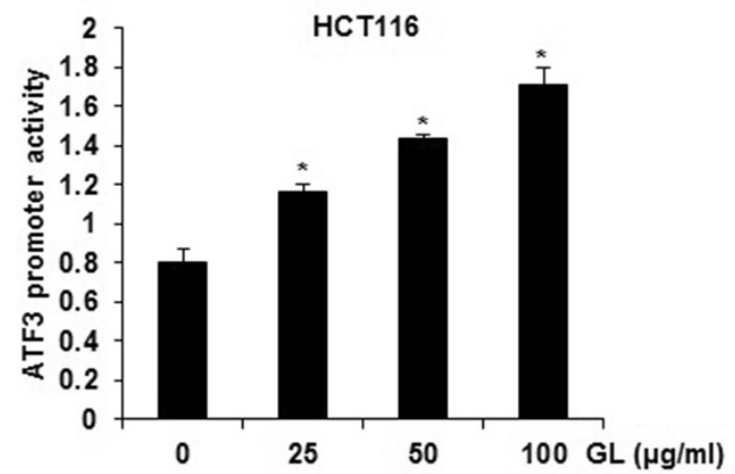

(G)

HCT116

\begin{tabular}{|c|c|c|c|c|c|c|}
\hline 0 & 1 & 3 & 6 & 10 & 24 & $\mathrm{GL}(100 \mu \mathrm{g} / \mathrm{ml}, \mathrm{h})$ \\
\hline & 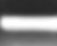 & 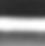 & - & 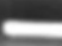 & 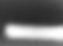 & ATF3 \\
\hline$=$ & 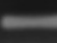 & 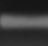 & - & $=$ & - & GAPDH \\
\hline
\end{tabular}

(B)

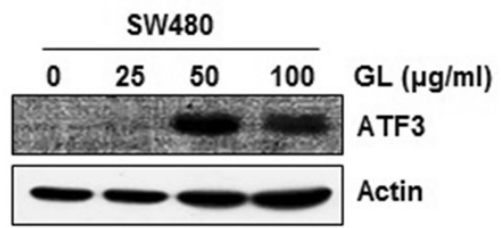

(D)

\begin{tabular}{|c|c|c|c|c|}
\hline \multicolumn{4}{|c|}{ SW480 } & \multirow[b]{2}{*}{$\mathrm{GL}(\mu \mathrm{g} / \mathrm{ml})$} \\
\hline 0 & 25 & 50 & 100 & \\
\hline & & 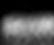 & & ATF3 \\
\hline & & & & GAPDH \\
\hline
\end{tabular}

(F)

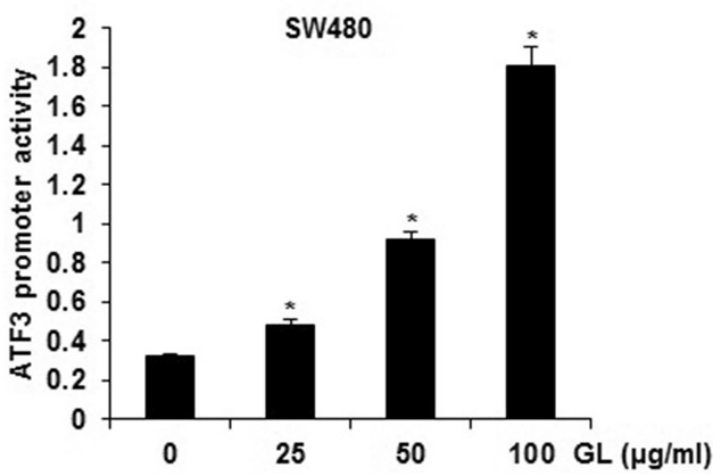

(H)

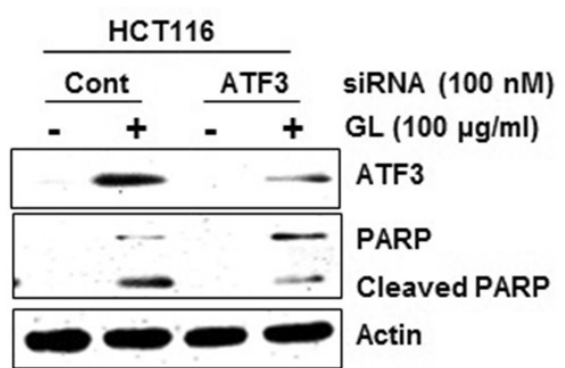

Figure 2 Effects of GL on ATF3 activation in human colorectal cancer cells. (A, B) HCT116 and SW480 cells were treated with 0, 25, 50 and $100 \mathrm{\mu g} / \mathrm{ml}$ of GL for $24 \mathrm{~h}$. Cell lysates were subjected to SDS-PAGE and the Western blot was performed using antibodies against ATF3. Actin was used as internal control. For RT-PCR analysis of ATF3 gene expression, total RNA was prepared after GL treatment for $24 \mathrm{~h}$ in dose-course experiments (C, D) or for the indicated times in time-course experiments (G). GAPDH were used as internal control. For ATF3 promoter activity, luciferase construct containing -1420 to +34 of human ATF3 promoter region was cotransfected with pRL-null vector and the cells were treated with GL for $24 \mathrm{~h}$ in dose-course experiments $(\mathbf{E}, \mathbf{F})$ and luciferase activity was measured. ${ }^{*} \mathrm{P}<0.05$ compared to cells without $\mathrm{GL}$ treatment. (H) ATF3 siRNA was transfected into HCT1 16 for $48 \mathrm{~h}$ and then GL was treated for $24 \mathrm{~h}$. Cell lysates were subjected to SDS-PAGE the Western blot was performed using antibodies against PARP. Actin was used as internal control.

and pATF3- 84/+ 34, respectively. Because GL increased ATF3 promoter activity more than 4.0-fold in SW480 cells, GL-responsible sites might be between -318 and -85 region of the ATF3 promoter. The Fushi tarazu (Ftz) and CREB is cis-acting elements in ATF3 promoter containing -147 and -85 by program (Gene Regulation, TFSEARCH, and Transcription Element System). To identify the role of each cis-acting element, each site-deleted ATF3 promoter constructs were transfected into SW480 cells and treated with $100 \mu \mathrm{g} / \mathrm{ml}$ of GL for $24 \mathrm{~h}$. As shown in Figure 4B, GL-induced ATF3 promoter activity was significantly decreased when the CREB site was deleted. However, the deletion of Ftz sites did not affect ATF3 promoter activity by GL. These data indicated that CREB is an important region in GL-induced ATF3 expression. 
(A)

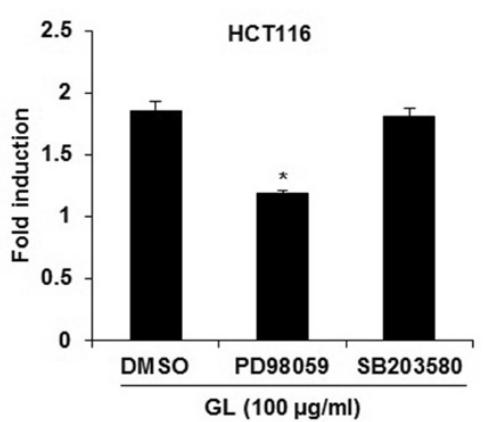

(C)

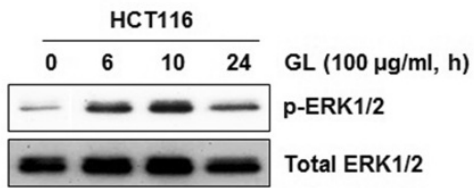

(E)

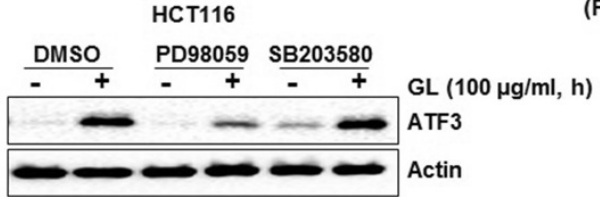

(B)

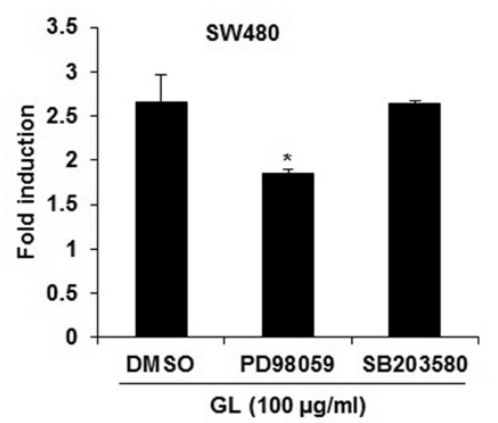

(D)

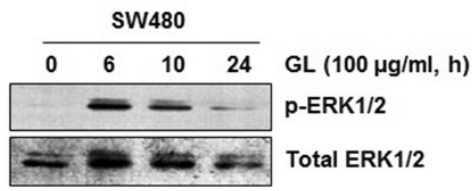

(F)

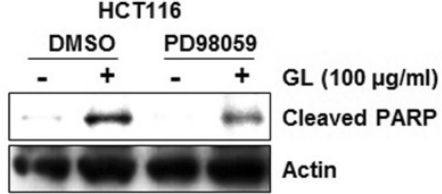

Figure 3 Up-stream signaling pathways affecting GL-mediated ATF3 activation. (A, B) Luciferase construct containing -1420 to +34 of human ATF3 promoter region was cotransfected with pRL-null vector. Then, the cells were pretreated with 20 HM of PD98059 (ERK1/2 inhibitor) or SB203580 (p38 inhibitor) and then cotreated with $100 \mu \mathrm{g} / \mathrm{ml}$ of GL for $24 \mathrm{~h} .{ }^{*} \mathrm{P}<0.05$ compared to cells without the treatment of inhibitors. (C, D) HCT116 and SW480 cells were treated with $100 \mu \mathrm{g} / \mathrm{ml}$ of GL for indicated times. Cell lysates were subjected to SDS-PAGE and the Western blot was performed using antibodies against p-ERK1/2 and ERK1/2. Actin was used as internal control. (E) HCT116 cells were pre-treated with $20 \mu \mathrm{M}$ of PD98059 (ERK1/2 inhibitor) or SB203580 (p38 inhibitor) and then co-treated with $100 \mu \mathrm{g} / \mathrm{ml}$ of EAFAD-B for 6 h. Cell lysates were subjected to SDS-PAGE the Western blot was performed using antibodies against ATF3. Actin was used as internal control. (F) HCT116 cells were pretreated with $20 \mu \mathrm{M}$ of PD98059 (ERK1/2 inhibitor) for $2 \mathrm{~h}$ and then co-treated with $100 \mu \mathrm{M}$ of GL for $24 \mathrm{~h}$. Cell lysates were subjected to SDS-PAGE the Western blot was performed using antibodies against PARP. Actin was used as internal control.

\section{Discussion}

Because many dietary factors exert anti-cancer activities, cancer chomoprevention with dietary factors has received attention as the most effective approach to reduce colorectal cancer-related mortality. Ginger leaves have been used as the dietary factors such a vegetable and tea, and the herbal medicine [5]. However, pharmacological actions of ginger leaves have not been studied. Here, we evaluated the anti-cancer activity of ginger leaves and elucidated its potential mechanism. In this study, we, for the first time, report that ginger leaves showed an anti-cancer activity associated with ATF3 activation in colorectal cancer cells,

ATF3, an ATF/CREB subfamily member, contains the basic-leucine zipper (b-ZIP) DNA binding domain [7]. ATF3 is dramatically expressed in response to several stresses in many different tissues and exerts diverse biological effects [7]. In cancer development, ATF3 exerts pro-or anti-apoptotic activities dependent on cell or tissue context $[8,9]$. ATF3 expression was suppressed in human colorectal cancer [10] and expression of ATF3 induced apoptosis, growth arrest of colorectal cancer cells and Ras-stimulated tumourigenesis [11-13]. On the other hand, ATF3 induces DNA synthesis and expression of cyclin D1 in hepatocellular carcinoma cells [14] and enhances cancer cell-initiating features in breast cancer [15]. Although ATF3 has dual effects in cancer development, ATF3 has been regarded as a major target of cancer chemoprevention in colorectal cancer. Our data indicate that GL increased ATF3 expression in both protein and mRNA level in a time- and dose-dependent manner through the activation of ATF3 promoter. In addition, it was reported that anti-cancer agents such as indole-3-carbinol [16], conjugated linoleic acid [17], epicatechin gallate [18], tolfenamic acid [19] and PI3 kinase inhibitor [13] induce ATF3dependent apoptosis in colorectal cancer cells. In our study, GL increased the PARP cleavage and reduced the viability of colorectal cancer cells, indicating that increased apoptosis and reduction of cell viability may be mediated by activation of ATF3 expression in GL-treated cells.

There is a growing body of evidence to suggest that MAPK signaling is an important pathway regulating ATF3 


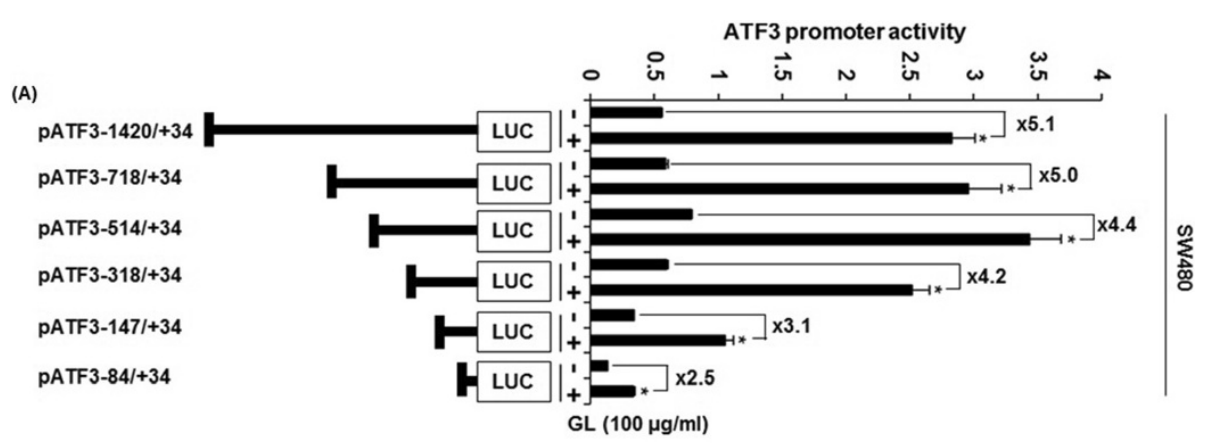

(B)

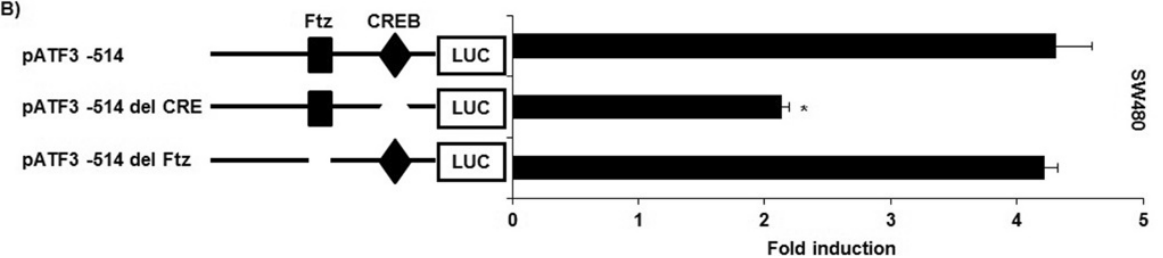

Figure 4 Identification of ATF3 promoter sites responsible for GL-induced ATF3 activation. (A). Each indicated construct of the ATF3 promoter $(0.5 \mu \mathrm{g})$ was co-transfected with $0.05 \mu \mathrm{g}$ of pRL-null vector into SW480 cells, and cells were treated with $100 \mu \mathrm{g} / \mathrm{ml}$ of GL for $24 \mathrm{~h}$. (B) Each deletion construct $(0.5 \mu \mathrm{g})$ of the ATF3 promoter was co-transfected with $0.05 \mu \mathrm{g}$ of pRL-null vector into SW480 cells and cells were treated with $100 \mathrm{\mu g} / \mathrm{ml}$ of GL for $24 \mathrm{~h}$. Luciferase activity was measured. *P $<0.05$ compared to cells without GL treatment.

expression $[18,20]$. Therefore, we examined whether GLmediated ATF3 activation is associated with the activation of ERK1/2, p38 and JNK. ERK1/2 inhibition by PD98059 attenuated GL-induced activation of ATF3 promoter and ATF3 expression but not in inhibition of p38 and JNK by SB203580 and bySP600125, indicating that ERK1/2 activation may contribute to GL-induced ATF3 activation. In addition, inhibition of ERK1/2 ameliorated GL-mediated apoptosis. In Western blot analysis for phosphorylation of ERK1/2, we found that GL induced a prolonged activation of ERK $1 / 2$. Why would late phase ERK activation correlate with proliferation and apoptosis remains to be understood. However, there is one hypothesis that prolonged activation of ERK1/2 can promote accumulation of $\mathrm{p} 21^{\text {cip } 1}$ resulting in cell cycle arrest and apoptosis [21]. Similarly, several anti-cancer agents have been reported to induce a prolonged activation of ERK1/2, which results in promoting apoptosis [22-25].

Interestingly, we found that GL-responsible sites for ATF3 activation might be between -318 and -85 region of the ATF3 promoter. ATF3 promoter includes various response elements such as AP-1, ATF/CRE, NF-kB, E2F and Myc/Max binding sites [26] and especially, EGR-1, CRE and Ftz are cis-acting elements in ATF3 promoter $(-318 /-85)$ [27] from which our data showed that GLinduced ATF3 promoter activity was significantly decreased when the CREB site was deleted. These data indicated that CREB is an important region in GL-induced ATF3 expression.

There is a report that ginger leaves has various bioactive compounds including quercetin, rutin, epicatechin, catechin, kaempferol, naringenin, salicylic acid, cinnamic acid, flavonoids and phenolics [28]. Among the bioactive compounds, quercetin has been reported to induce ATF3 expression in human colorectal cancer cells, Caco-2 [29]. Interestingly, we found that ginger leaves had more quercetin $(2.124 \mathrm{mg} / \mathrm{g}$ dry weight) than ginger rhizoma $(1.105 \mathrm{mg} / \mathrm{g}$ dry weight), which is similar to the previous report [28]. According to the previous study [30,31] quercetin can be efficiently hydrolysed and absorbed in the intestinal lumen and plasma. Therefore, it is thought that quercetin may be responsible for ATF3-mediated apoptosis by ginger leaves in human colorectal cancer cells and quercetin of GL may be absorbed in the intestinal lumen and plasma of animal.

\section{Conclusions}

In conclusion, ginger leaves may induce apoptosis and reduction of cell viability, followed by the increased ATF3 expression via activating ATF3 promoter in human colorectal cancer cells. In addition, there is a growing evidence that ginger leaves had higher antioxidant activity than rhizomes and flowers Eric Chan et al. [5]. Therefore, ginger leaves has great potential to be developed into functional foods and other health products.

\section{Competing interests}

The authors declare that they have no competing interests.

\section{Authors' contributions}

JBJ directed and GHP, JHP \& HMS designed the study. JHP undertook the formal identification of the leaves of ginger (Zingiber officinale). GHP, JHP, HMS HJE, MKK, JWL, MHL, K-HC, JRL and HJC performed the experiments. GHP, JHP 
and HMS drafted manuscript. HJE, MKK, JWL, MHL, K-HC, JRL, HJC and JBJ corrected the manuscript. All authors read and approved the final manuscript.

\section{Acknowledgements}

We thank Dr. Seong-Ho Lee (University of Maryland College Park, MD, USA) for providing ATF3 promoter (pATF3-1420/+34, pATF3- 718/+ 34, pATF3- 514/+ 34, pATF3- 318/+ 34, pATF3-147/+ 34, and pATF3- 84/+34). This work was supported by the BK21 PLUS program of Ministry of Education, the Ministry of Education, Science and Technology (2011-0025272), and by a grant from 2014 Research Fund of Andong National University (2014-0169).

\section{Author details}

'Department of Bioresource Sciences, Andong National University, Andong 760749, South Korea. ${ }^{2}$ Department of Medicinal Plant Science, Jungwon University, Goesan 367805, South Korea. ${ }^{3}$ Gyeongbuk Institute for Bio-industry, Andong 760380, South Korea. ${ }^{4}$ Insititute of Agricultural Science and Technology, Andong National University, Andong 760749, South Korea. ${ }^{5}$ Department of Medicinal Plant Resources, Andong National University, Andong 760749, South Korea.

\section{Received: 28 June 2014 Accepted: 15 October 2014}

Published: 23 October 2014

\section{References}

1. Siegel R, Naishadham D, Jemal A: Cancer statistics, 2013. CA Cancer J Clin 2013, 63:11-30.

2. Wang H, Khor TO, Shu L, Su ZY, Fuentes F, Lee JH, Kong AN: Plants vs. cancer: a review on natural phytochemicals in preventing and treating cancers and their druggability. Anti-Cancer Agents Med Chem 2012, 12:1281-1305

3. Yeh CT, Yen GC: Chemopreventive functions of sulforaphane: a potent inducer of antioxidant enzymes and apoptosis. J Funct Foods 2009, 1:23-32.

4. Rasmussen P: Ginger-Zingiber officinale Roscoe, Zingiberaceae. J Prim Health Care 2011, 3:235-236

5. Eric Chan WC, Lim YY, Wong SK: Antioxidant properties of ginger leaves: an overview. Free Radic Res 2011, 1:6-16.

6. Lee SH, Min KW, Zhang X, Baek SJ: 3,3'-diindolylmethane induces activating transcription factor 3 (ATF3) via ATF4 in human colorectal cancer cells. J Nutr Biochem 2013, 24:664-671.

7. Hai T, Hartman MG: The molecular biology and nomenclature of the activating transcription factor/cAMP responsive element binding family of transcription factors: activating transcription factor proteins and homeostasis. Gene 2001, 273:1-11.

8. Miyazaki K, Inoue S, Yamada K, Watanabe M, Liu Q, Watanabe T, Adachi MT, Tanaka Y, Kitajima S: Differential usage of alternate promoters of the human stress response gene ATF3 in stress response and cancer cells. Nucleic Acids Res 2009, 37:1438-1451.

9. Yin X, Dewille JW, Hai T: A potential dichotomous role of ATF3, an adaptive-response gene, in cancer development. Oncogene 2008, 27:2118-2127

10. Bottone FG Jr, Martinez JM, Alston-Mills B, Eling TE: Gene modulation by Cox-1 and Cox-2 specific inhibitors in human colorectal carcinoma cancer cells. Carcinogenesis 2004, 25:349-357.

11. Fan F, Jin S, Amundson SA, Tong T, Fan W, Zhao H, Zhu X, Mazzacurati L, Li $X$, Petrik KL, Fornace AJ Jr, Rajasekaran B, Zhan Q: ATF3 induction following DNA damage is regulated by distinct signaling pathways and overexpression of ATF3 protein suppresses cells growth. Oncogene 2002, 21:7488-7496.

12. Lu D, Wolfgang CD, Hai T: Activating transcription factor 3, a stressinducible gene, suppresses Ras-stimulated tumorigenesis. J Biol Chem 2006, 281:10473-10481.

13. Yamaguchi K, Lee SH, Kim JS, Wimalasena J, Kitajima S, Baek SJ: Activating transcription factor 3 and early growth response 1 are the novel targets of LY294002 in a phosphatidylinositol 3-kinase-independent pathway. Cancer Res 2006, 66:2376-2384.

14. Allan AL, Albanese C, Pestell RG, LaMarre J: Activating transcription factor 3 induces DNA synthesis and expression of cyclin D1 in hepatocytes. J Biol Chem 2001, 276:27272-27280.

15. Yin X, Wolford CC, Chang YS, MCConoughey SJ, Ramsey SA, Aderem A, Hai T: ATF 3 , an adaptive-response gene, enhances TGF $\{$ beta\} signaling and cancer-initiating cell features in breast cancer cells. J Cell Sci 2010, 123:3558-3565.

16. Lee SH, Kim JS, Yamaguchi K, Eling TE, Baek SJ: Indole-3-carbinol and 3,3'diindolylmethane induce expression of NAG-1 in a p53-independent manner. Biochem Bioph Res Co 2005, 328:63-69.

17. Lee SH, Yamaguchi K, Kim JS, Eling TE, Safe S, Park Y, Baek SJ: Conjugated linoleic acid stimulates an anti-tumorigenic protein NAG-1 in an isomer specific manner. Carcinogenesis 2006, 27:972-981.

18. Baek SJ, Kim JS, Jackson FR, Eling TE, McEntee MF, Lee SH: Epicatechin gallate-induced expression of NAG-1 is associated with growth inhibition and apoptosis in colon cancer cells. Carcinogenesis 2004, 25:2425-2432.

19. Lee SH, Bahn JH, Whitlock NC, Baek SJ: Activating transcription factor 2 (ATF2) controls tolfenamic acid-induced ATF3 expression via MAP kinase pathways. Oncogene 2010, 29:5182-5192.

20. Lu D, Chen J, Hai T: The regulation of ATF3 gene expression by mitogenactivated protein kinases. Biochem J 2007, 401:559-567.

21. Chambard JC, Lefloch R, Pouyssequr J, Lenormand P: ERK implication in cell cycle regulation. Biochim Biophys Acta 2007, 1773:1299-1310.

22. Xio D, Singh SV: Phenethyl isothiocyanate-induced apoptosis in p53deficient PC-3 human prostate cancer cell line is mediated by extracellular signal-regulated kinases. Cancer Res 2002, 62:3615-3619.

23. Tang D, Wu D, Hirao A, Lahti JM, Liu L, Mazza B, Kidd VJ, Mak TW, Ingram AJ: ERK activation mediates cell cycle arrest and apoptosis after DNA damage independently of p53. J Biol Chem 2007, 277:12710-12717.

24. Hsu YL, Kuo OL, Lin LT, Lin CC: Asiatic acid, a triterpene, induces apoptosis and cell cycle arrest through activation of extracellular signalregulated kinase and p38 mitogen-activated protein kinase pathways in human breast cancer cells. J Pharmacol Exp Ther 2005, 313:333-344.

25. Calcabrini A, Garcia-Martinez JM, Gonzalez L, Tendero MJ, Ortuno MT, Crateri P, Lopez-Rivas A, Arancia G, Gonzalez-Porque P, Martin-Perez J: Inhibition of proliferation and induction of apoptosis in human breast cancer cells by lauryl gallate. Carcinogenesis 2006, 27:1699-1712.

26. Liang G, Wolfgang CD, Chen BP, Chen TH, Hai T: ATF3 gene. Genomic organization, promoter, and regulation. J Biol Chem 1996, 271:1695-1701.

27. Cho KN, Sukhthankar M, Lee SH, Yoon JH, Baek SJ: Green tea catechin (-)-epicatechin gallate induces tumour suppressor protein ATF3 via EGR-1 activation. Eur J Cancer 2007, 43:2404-2412.

28. Ghasemzadeh A, Jaafar HZ, Rahmat A: Synthesis of phenolics and flavonoids in ginger (Zingiber officinale Roscoe) and their effects on photosynthesis rate. Int J Mol Sci 2011, 11:4539-4555.

29. Dihal AA, Tilburgs C, van Erk MJ, Rietjens IM, Woutersen RA, Stierum RH: Pathway and single gene analyses of inhibited Caco-2 differentiation by ascorbate-stabilized quercetin suggest enhancement of cellular processes associated with development of colon cancer. Mol Nutr Food Res 2007, 51:1031-1045.

30. Walle T, Otake Y, Walle UK, Wilson FA: Quercetin glucosides are completely hydrolyzed in ileostomy patients before absorption. J Nutr 2000, 130:2658-2661.

31. Crespy V, Morand C, Manach C, Besson C, Demigne C, Remesy C: Part of quercetin absorbed in the small intestine is conjugated and further secreted in the intestinal lumen. Am J Physiol 1999, 277:120-126.

\section{doi:10.1186/1472-6882-14-408}

Cite this article as: Park et al:: Anti-cancer activity of Ginger (Zingiber officinale) leaf through the expression of activating transcription factor 3 in human colorectal cancer cells. BMC Complementary and Alternative Medicine 2014 14:408. 